The closing pages are devoted to biographical notices, the first to figure being the founder of the original "Anales" in 1894 . On the whole, the new journal gives a pleasing impression, and, if the promise of this first number is maintained, it will form a worthy and authoritative expression of the best in Spanish ophthalmology. It runs to eighty-one pages of matter, is well printed on fine paper, generously illustrated, and well bound. It purports to come out monthly, and is obtainable from the Imp. de Cleto Vallinas, Luisa Fernanda, 5, Madrid. The annual subscription for foreign countries is thirty pesetas (or about 18s.).

\title{
CORRESPONDENCE
}

\section{TINTS AND THEIR VALUE}

\section{To the Editor of The British Journal of Ophthalmology}

SiR,-Sir Arnold Lawson's interesting address on "Tints and their Value," in the March issue recalls some work on similar lines which I did in the Physiology Dept. of the University of Melbourne under the direction of Professor W.A. Osborne. The results were published in the "Medical Journal of Australia," September 2, 1922, page 268. Using A. Hilger's quartz spectrograph and an iron arc, various solutions, spectacle glass and living tissue of eyes, readings were made from the negatives. We did not go into the matter with the experience in the use of the spectrograph or to the extent to which Dr. Judd Lewis has now done, but the conclusions were relatively much the same. It was shown that cornea transmitted rays from $2938 \AA$ in the white rabbit to $3046 \AA$ in the dog, while our lens readings varied from $3049^{\circ}$ in white rabbit to $3165^{\circ}$ in the bullock. Dr. Judd Lewis's readings are $2900 \AA$ for cornea and $3500 \AA$ for lens. The difference in lental readings may be due to the using in our case of crushed lens matter in the quartz containers-otherwise it seemed impossible to get the same thickness of lens $(10 \mathrm{~mm}$.) for all experiments.

Would Sir Arnold Lawson or Dr. Judd Lewis be good enough to give an opinion and also state what animals were used?

$$
\text { Yours faithfully, }
$$

LeOnard Mitchell.

Melbourne, Australia. April 14, 1925. 